ity of the scholar, is a hard thing to admit. Shiflett has more than adequate documentation for this finding.

It is also somewhat painful to have so clearly documented the fact that the kind of education that librarians and their academic institutions accepted ". . . differed radically from that expected of faculty members. Indeed, the form of library education as it was begun by Dewey and promoted by his disciples was, in essence, a manifestation of the spirit of the public library movement." So much for the strength of the historical influence as regards academic status for librarians.

In Shiflett's words: “As a profession distinguishable from that of members of the faculty and from other types of librarians, it (academic librarianship) has failed to become fully defined." Rather, I would say that, after reading Shiflett, the definition might well be before us. Now all we have to do is admit it-academic librarians warrant status on their own account. Shiflett has provided us with plenty of food for thought.-Russell Shank, University of California at Los Angeles.

College Librarianship. Ed. by William C. Miller and C. Stephen Rockwood. Metuchen, N.J., and London: Scarecrow, 1981. 284p. \$15. LC 80-25546 ISBN 0-81081383-1.

One of the many undercurrents of academic librarianship is the persistent notion that small-college libraries have special problems which cannot be treated easily. Somehow the environment and limited resources of the typical host institution seem to impose peculiar restraints on the library's potential for achieving success. This perception is especially evident among those librarians who view the difference between college and university settings as basically a matter of scale. Fortunately, most of the people who contributed essays and studies to the publication reviewed here recognize the unique and exciting challenges afforded by a venture into college librarianship.

This is a modest book which offers the reader an opportunity to reflect on such vexing issues as "Collection Development from a College Perspective," "The Challenge of Cataloging in the College Environment," and "Equal Employment Opportunity and the College Library Administrator." Two of the eighteen articles were published earlier in $C \& R L$, but the rest of them are fresh contributions to the relatively sparse literature on the subject. In all, they serve as a good introduction to a variety of topics handled by college librarians on a daily basis.

The most refreshing articles are those that attempt to come to terms with the special characteristics of the subject in a general manner. Peter Dollard's overview, entitled "A Paradigm for College Libraries," is a remarkably thoughtful attempt to delineate the special role of the college library. Susan Lee offers a superb planning strategy in "A Modest Management Approach," while Charles Maurer describes the underlying paradox of mixed responsibility for line and staff functions with "Close Encounters of Diverse Kinds: A Management Panorama for the Director of the Smaller College Library." Other articles focus on topics such as faculty status, acquisitions, personnel, media resources, user instruction, government documents, archives, and planning a library building. In all, the editors have assembled a serviceable treatment of the subject.

This volume should be useful to library school students and others who may wish to obtain greater knowledge of the real issues faced by college librarians. It may also serve to identify some topics for research in an area of librarianship which some people feel has not received enough attention.-Richard $A$. Olsen, Rhode Island College, Providence.

Slater, Margaret. Ratios of Staff to Users: Implications for Library-Information Work and the Potential for Automation. (Aslib Occasional Publication no.24.) London: Aslib, 1981. 123p. \$17, U.K. (\$14, Aslib members), $\$ 21.25$, U.S. ( $\$ 17.50$, Aslib members).

This report is the result of a study conducted by the Aslib Research and Consultancy Division and funded by the British Library Research and Development Department. The aim of the study was to provide ratios of library-information staff to users in the special sector (excluding public library and educational sectors). These ratios are intended to be of use in forecasting and planning at both the national and organizational 


\section{NEW FROM NOYES}

Available Fall 1982

BIOLOGICAL ASPECTS OF COPPER-Occurrence, Assay and Interrelationships by Charles A. Owen, Jr.: ISBN 0-8155-0918-9; $\$ 28$.

C1-BASED CHEMICALS FROM HYDROGEN AND CARBON MONOXIDE edited by M.T. Gillies: ISBN $0-8155-0901-4 ; \$ 47$.

DEPOSITION TECHNOLOGIES FOR FILMS AND COATINGS by Rointan F. Bunshah et al.: ISBN 0-8155-0906-5; $\$ 69$.

ELECTRODEPOSITION PROCESSES, EQUIPMENT AND COMPOSITIONS edited by J.I. Duffy: ISBN 0-8155-0898-0; $\$ 42$.

ELECTROSTATIC PRECIPITATOR MANUAL by Jack R. MeDonald and Alan H. Dean: ISBN 0-8155-0895-6; $\$ 48$.

ETCHING COMPOSITIONS AND PROCESSES edited by M.J. Collie: ISBN 0-8155-0913-8; $\$ 42$.

FABRIC FORMING SYSTEMS by Peter Schwartz et al.: ISBN 0-8155-0908-1; $\$ 24$.

HANDBOOK FOR FLUE GAS DESULFURIZATION SCRUBBING WITH LIMESTONE by D.S. Henzel et al.: ISBN 0-8155-0912-X; $\$ 44$.

HANDBOOK OF ADHESIVE RAW MATERIALS by Ernest W. Flick: ISBN 0-8155-0897-2; $\$ 45$.

HANDBOOK OF COAL-BASED ELECTRIC POWER GENERATION by Robert H. Shannon: ISBN 0-8155-0907-3; $\$ 45$.

HAZARDOUS WASTE LEACHATE MANAGEMENT MANUAL by Alan J. Shuckrow et al.: 'ISBN 0-8155-0910-3; $\$ 36$.

HEAVY OIL AND TAR SANDS RECOVERY AND UPGRADING edited by M.M. Schumacher: ISBN 0-8155-0893-X; \$48.

IGUANAS OF THE WORLD-Their Behavior, Ecology, and Conservation edited by Gordon M. Burghardt and A. Stanley Rand: ISBN 0-8155-0917-0; \$55.

INTERNATIONAL TECHNOLOGY FOR THE NONFERROUS SMELTING INDUSTRY by T.K. Corwin et al.: ISBN 0-8155-0894-8; $\$ 36$.

LOW-RANK COAL TECHNOLOGY-Lignite and Subbituminous by G.H. Gronhovd et al.: ISBN 0-8155-0896-4; $\$ 52$.

METAL SURFACE TREATMENT-Chemical and Electrochemical Surface Conversion edited by M.H. Gutcho: ISBN 0-8155-0900-6; $\$ 48$.

NUTRITION AND KILLER DISEASES edited by John Rose: ISBN 0-8155-0902-2; $\$ 25$.

PHYSIOLOGICAL ASPECTS OF COPPER-Copper in Organs and Systems by Charles A. Owen, Jr.: ISBN 0-8155-0904-9; $\$ 28$.

PLANT GROWTH REGULATORS AND HERBICIDE ANTAGONISTS edited by J.C. Johnson: ISBN 0-8155-0915-4; \$45.

POLISHING AND WAXING COMPOSITIONS-Recent Developments edited by M.G. Halpern: ISBN 0-8155-0916-2; $\$ 36$.

PREEMERGENCE HERBICIDES-Recent Advances edited by $\mathrm{S}$. Torrey: ISBN 0-8155-0914-6; $\$ 48$.

PRINCIPLES AND TECHNIQUES IN DIAGNOSTIC HISTOPATHOLOGY by Jules M. Elias: ISBN 0-8155-0903-0; $\$ 48$.

RESOURCE RECOVERY PROCESSING EQUIPMENT by David Bendersky et al. and George M. Savage et al.: ISBN 0-8155-0911-1; \$42.

SYNTHETIC OILS AND LUBRICANT ADDITIVES-Advances Since 1979 edited by M.J. Satriana: ISBN 0-8155-0899-9; $\$ 48$.

THIN SEAM COAL MINING TECHNOLOGY by J. Clark et al.: ISBN 0-8155-0909-X; $\$ 36$.

TRANSPORTATION ENERGY DATA BOOK-Sixth Edition by G. Kulp and M.C. Holcomb: ISBN 0-8155-0919-7; $\$ 36$.

WOLVES OF THE WORLD-Perspectives of Behavior, Ecology, and Conservation edited by Fred H. Harrington and Paul C. Paquet: ISBN 0-8155-0905-7; \$48. 
level, and are intended to complement ratios used for forecasting in other areas of manpower planning in the United Kingdom.

Census data came from two sources published in 1978. Additional data was gathered from a questionnaire that was distributed to 2,100 special service units, of which 655 (31 percent) replied. These 655 units were divided into three categories: industrycommerce, private and profit-making; government, central and local; and societies and associations. There were also categories for geographical distribution and size of parent organization. Ratios were established for two types of staffing-staff with special qualifications and total staff. Users were defined as either on-site or off-site. Potential and theoretically possible user populations were also discussed. In addition, the questionnaire was designed to address the issue of ideal ratios needed to maintain current services and those needed to expand services. Work-load ratios were also collected.

Whether the ratios constructed in the report have utility for U.S. planners can be left to the judgment of the reader. It is interesting to compare the discussion sections of this re- port with the "National Profile of Information Professionals," by Donald W. King, et al., in the Bulletin of the American Society of Information Science (August 1980). On both sides of the ocean there is concern over the lack of national standards relating to information professionals, and a lack of information concerning the number of specialists needed, or what training they should have. The Slater report echoes the King report in finding that technical or other "special" credentials or training is frequently substituted for training in the principles of information extraction in many units serving the special sector. Slater takes the optimistic view that these staff positions may in the future be filled by people with more formal qualifications. Both reports, however, indicate a lack of appreciation of such special qualifications on the part of employers. Indeed, there appears to be a lack of consensus on the part of the specialists themselves about their own identity as a profession. Slater reports a lack of agreement even on the names given to these units, with the term "Library" coming under special fire. Her findings showed the more unique the label, the happier the staff

\section{Engineering Index} publications. Abstracts of virtually every important article published in every engineering discipline. Last month. Last year. Or as far back as 1884 .

Call toll-free or write for copies of our folder "A Complete Guide to Engineering Index Publications," yours to distribute free.

\section{Engineering (Ei) Information, Inc. 345 East 47 th Street New York, New York 10017 Call toll-free 800-221-1044 In New York State. call 212-705-7615}

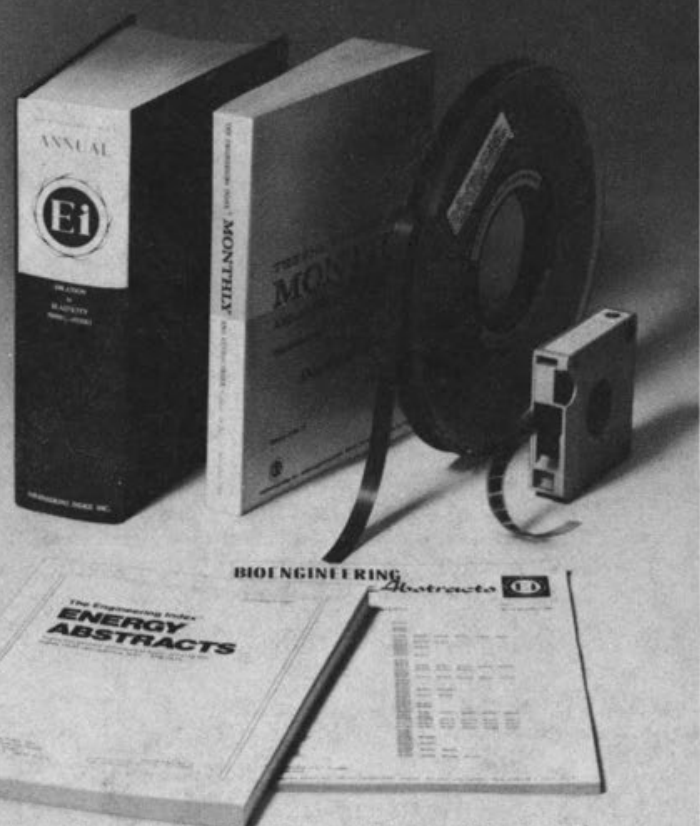

Publishers of Engineering Index* Monthly, Engineering Index Annual, Energy Abstracts, Bioengineering Abstracts, and Compendex* 
seemed to be with it, as it reflected some specific focus of their operation not captured by a more generic term.

Despite the inclusion of automation in the subtitle, there is not great emphasis on this aspect of library/information work in the report. The questionnaire asked about current usage and desire to automate, but readers are left to draw their own conclusions about its future impact.-Charlene Renner, Iowa State University, Ames.

\section{Chen, Ching-chih. Zero-Base Budgeting in} Library Management: A Manual for Librarians. Phoenix: Oryx Press, 1980. 290p. $\$ 27.50$. LC 80-12055. ISBN 0-912700-181.

The author, who describes herself as neither advocate nor detractor of zero-base budgeting (ZBB), has addressed her work to library managers who seek information about this recently heralded theory/process, "to decide whether ZBB can be a meaningful and suitable process for them in planning, budgeting, evaluation, and control." Portions of the material presented were developed for institutes on ZBB directed by the author in 1978.

Following a section on "Fundamentals of Budgeting" (ten pages), Chen offers general background (eight pages), and some thirty pages of more detailed explanation of the special elements (e.g., "decision packages") of ZBB. She concludes the narrative section of the book with a short chapter (four pages) on advantages and disadvantages of ZBB, and then six pages on "Managing ZBB and Its Implications for Library Managers." Most of the remainder (some two hundred pages) of the book is taken up with examples, almost entirely reproductions of both blank and completed ZBB budget documents from three special libraries: a state library, two medium-sized university libraries, and one college library. A glossary, bibliography, and index complete the volume.

The fundamental weakness of the work stems from its origins as a collection of material intended for use in an institute, where an instructor or leader can provide both context and answers to questions. The book is wanting - certainly as a "manual"-in that both the general discussion and the examples of ZBB applications are presented without context or the critical analysis and commentary needed by many readers, especially those not well versed in budgeting issues. A more substantive review of general budgeting principles and theory (more than one paragraph to describe program or performance budgeting, for example) would have strengthened this work considerably. Fewer examples, with explication of and fuller commentary on the details of library applications of ZBB would have been most useful. Numerous stylistic, and some grammatical, lapses also suggest haste in editing and production.

While references to other works on ZBB are many and valuable, all but a scattered few date from ZBB's halcyon period of 1975-77. There are more recent and useful comprehensive analyses of $\mathrm{ZBB}$, such as Hammond and Knott's Zero-Based Look at Zero-Base Budgeting (published in 1980), that the librarian-manager should consult.

This would be an appropriate acquisition for larger library-science collections, but, especially at the quoted price, it is not recommended to others. - William J. Crowe, Ohio State University Libraries, Columbus.

Boss, Richard, and Raikes, Deborah. Developing Microform Reading Facilities. Westport, Conn.: Microform Review, 1981. 198p. \$39.95. LC 81-3963. ISBN 0913672-09-2.

The latest volume in the Microform Review series in library micrographics management, Developing Microform Reading Facilities, is magazine sized, with lots of photographs and not much text, considering the size. The price, moreover, is a rather steep $\$ 39.95$. Nonetheless, the information it contains is accurate, complete, well illustrated, and certainly useful to anyone contemplating designing a microforms-reading area. It is clear that the authors have had "hands on" experience with microforms and know whereof they speak; their recommendations are both practical and reasonable.

The book is divided into five chapters, plus an introduction and a conclusion. The first three chapters discuss the various microformats and such things as reduction ratios, silver versus nonsilver film, and the physical care of microforms. Other topics covered in these chapters are locating and preparing a 